\title{
Sensitivity simulations with direct shortwave radiative forcing by aeolian dust during glacial cycles
}

\author{
E. Bauer and A. Ganopolski \\ Potsdam Institute for Climate Impact Research, P.O. Box 601203, 14412 Potsdam, Germany \\ Correspondence to: E. Bauer (eva.bauer@ pik-potsdam.de)
}

Received: 16 December 2013 - Published in Clim. Past Discuss.: 13 January 2014

Revised: 12 May 2014 - Accepted: 30 May 2014 - Published: 17 July 2014

\begin{abstract}
Possible feedback effects between aeolian dust, climate and ice sheets are studied for the first time with an Earth system model of intermediate complexity over the late Pleistocene period. Correlations between climate and dust deposition records suggest that aeolian dust potentially plays an important role for the evolution of glacial cycles. Here climatic effects from the dust direct radiative forcing (DRF) caused by absorption and scattering of solar radiation are investigated. Key elements controlling the dust DRF are the atmospheric dust distribution and the absorption-scattering efficiency of dust aerosols. Effective physical parameters in the description of these elements are varied within uncertainty ranges known from available data and detailed model studies. Although the parameters can be reasonably constrained, the simulated dust DRF spans a wide uncertainty range related to the strong nonlinearity of the Earth system. In our simulations, the dust DRF is highly localized. Medium-range parameters result in negative DRF of several watts per square metre in regions close to major dust sources and negligible values elsewhere. In the case of high absorption efficiency, the local dust DRF can reach positive values and the global mean DRF can be insignificantly small. In the case of low absorption efficiency, the dust DRF can produce a significant global cooling in glacial periods, which leads to a doubling of the maximum glacial ice volume relative to the case with small dust DRF. DRF-induced temperature and precipitation changes can either be attenuated or amplified through a feedback loop involving the dust cycle. The sensitivity experiments suggest that depending on dust optical parameters, dust DRF has the potential to either damp or reinforce glacial-interglacial climate changes.
\end{abstract}

\section{Introduction}

Mineral dust aerosols are abundant in the atmosphere and have the potential to alter the energy budget of the Earth by inducing a radiative forcing at the top of the atmosphere (TOA) via absorbing and scattering of radiation fluxes. Global and annual means of the dust radiative forcing can be small but are connected with relatively large standard deviations related to spatial heterogeneity and seasonal variability. It is unclear to which extent the naturally varying radiative forcing by atmospheric dust particles leads to internal climate variability or plays a role in shaping the glacial-interglacial climate changes. More widely accepted are the ideas that the darkening of ice and snow fields by dust deposition (Warren and Wiscombe, 1980) is important for explaining the extent and melting of ice sheets (Krinner et al., 2006; Ganopolski et al., 2010), and that the iron fertilization of the marine biota by mineral dust (Martin, 1990) is important for reproducing the global carbon cycle (Archer et al., 2000; Bopp et al., 2003; Brovkin et al., 2012; Watson et al., 2000).

The aeolian dust concentration in the atmosphere fluctuates over orders of magnitude in space and time due to variations in dust emission, wind-driven transport and deposition. In terms of dust mass, the atmospheric dust load per surface area is more than 3 orders of magnitude larger at low latitudes than at polar latitudes. This spatial irregular dust distribution is attributed to the short atmospheric residence time of about several days, much shorter than the residence time of the well-mixed greenhouse gases.

For present day, a consistent picture of the emission inventories and the atmospheric loads of primary aerosols (i.e. dust, sea salt, sulfate, organic matter and soot) has been generated by the comprehensive analysis of the AEROsol interCOMparison (AEROCOM) project (aerocom.met.no). 
The global dust load has an annual mean value of $19.2 \mathrm{Tg}$ $\left(1 \mathrm{Tg}=10^{12} \mathrm{~g}\right)$ and a median of $20.5 \mathrm{Tg}$, which means that mineral dust aerosols constitute about $60 \%$ of the dry mass of atmospheric aerosols (Dentener et al., 2006; Textor et al., 2006). A mean residence time of about four days is obtained from simulating the removal process of dust aerosols based on 16 different circulation models (Textor et al., 2006). The corresponding mean dust emission flux is $1840 \mathrm{Tg} \mathrm{yr}^{-1}$ with a median of $1640 \mathrm{Tg} \mathrm{yr}^{-1}$. These results on the dust life cycle depend on model parameterizations as shown by the harmonized emission experiment in which aerosol emissions, injection heights and particle sizes at dust sources are prescribed (Textor et al., 2007).

For palaeotimes, dust proxy data from different sediment and ice cores indicate increased deposition fluxes of dust mass during the Last Glacial Maximum (LGM, about 21000 yr before present) compared to Holocene climate conditions (Kohfeld and Harrison, 2001; Maher et al., 2010). Deposition fluxes are larger in glacials than in interglacials by a factor of 2-2.5 in the equatorial Pacific (Anderson et al., 2006; Winckler et al., 2008) and by a factor of roughly 25 in Antarctica (Petit et al., 1999; Lambert et al., 2008). A major cause of glacial-interglacial changes in dust deposition is presumably the changing dust emission from changes in vegetation distribution and sediment export from glacial erosion. The use of the BIOME3 model which accounts for the carbon dioxide $\left(\mathrm{CO}_{2}\right)$ fertilization of vegetation (Haxeltine and Prentice, 1996) shows that the dust emission can grow from $8040 \mathrm{Tg} \mathrm{yr}^{-1}$ in preindustrial times to $10880 \mathrm{Tg} \mathrm{yr}^{-1}$ at LGM, which can increase further to $14020 \mathrm{Tg} \mathrm{yr}^{-1}$ if also glaciogenic dust production is considered (Mahowald et al., 2006b).

Possible answers on how the associated atmospheric dust load and the dust radiative forcing could have differed between glacial and interglacial climates, and which impact the dust radiative forcing might have had for the climate evolution are to be studied with climate system models coupled to a dust cycle model. Currently, different dust cycle models are operational and they show a wide divergence in dust radiative forcing (Cakmur et al., 2006; Chin et al., 2002; Ginoux et al., 2006; Grini et al., 2005; Liao et al., 2004; Lunt and Valdes, 2002; Luo et al., 2003; Mahowald et al., 2006a; Miller et al., 2006; Myhre et al., 2003; Reddy et al., 2005; Takemura et al., 2009; Tanaka and Chiba, 2006; Tegen et al., 2002; Werner et al., 2002). Model simulations on the climate response to the dust radiative forcing are still rare. A first study shows that the dust radiative forcing can produce a surface cooling of about $-1 \mathrm{~K}$ for LGM conditions and of $-0.4 \mathrm{~K}$ for preindustrial conditions (Mahowald et al., 2006b).

The dust radiative forcing at TOA depends on dust load and particle size distribution and varies with climate variables such as radiation fluxes, surface albedo and cloudiness. Using realistic size and optical characteristics, the direct shortwave radiative forcing by dust gets increasingly negative with increasing dust load over dark surfaces and, in- versely, increasingly positive with increasing dust load over bright surfaces. At glacials, the larger dust load is accompanied with a larger surface albedo. Due to increased ice and snow cover and decreased vegetation cover, the global mean surface albedo is increased at LGM by about $30 \%$ compared to present day. Hence, the dust radiative forcing is expected to vary with long-term seasonal and regional changes in surface albedo, dust emission and dynamics of the atmosphere.

The dust radiative forcing depends further on microphysical properties, such as particle shape, mineralogy and mixing state among different aerosols. The broad range of dust particle sizes from less than 0.01 to more than $10 \mu \mathrm{m}$ (Tegen and Lacis, 1996; Myhre and Stordal, 2001) complicates the calculation of dust radiative forcing because the dust optical parameters are sensitive to particle size and radiation wavelength (Otto et al., 2009). Of particular relevance for the present study is that the imaginary part of the refractive index (RI; see Appendix) for visible wavelengths (0.3$0.7 \mu \mathrm{m}$ ) is found to be a factor of 2 to 6 smaller than considered earlier (Dubovik et al., 2002; Kinne et al., 2006; Balkanski et al., 2007). This explains partly the diverse results on radiative forcing by mineral dust obtained by earlier studies (Overpeck et al., 1996; Tegen et al., 1996; Claquin et al., 1998). Recent estimates of the global mean shortwave forcing at TOA by aeolian dust with revised values of RI lie between $-0.28 \mathrm{~W} \mathrm{~m}^{-2}$ (Reddy et al., 2005) and $-0.68 \mathrm{~W} \mathrm{~m}^{-2}$ (Balkanski et al., 2007) for present-day all-sky conditions.

Calculations of the direct dust radiative forcing at TOA with a global climate model for LGM and present-day time slices by Claquin et al. (2003) utilize the dust fields simulated by Mahowald et al. (1999). These dust fields are vertically integrated and transformed to aerosol optical thickness (AOT) at a wavelength of $0.55 \mu \mathrm{m}$, resulting in mean AOT of 0.14 and 0.05 for LGM and modern climates, respectively. The net direct radiative forcing from combining shortwave and longwave forcing is given to be $-3.2 \mathrm{~W} \mathrm{~m}^{-2}$ for LGM climate and $-1.2 \mathrm{~W} \mathrm{~m}^{-2}$ for modern climate if external mixing of mineral dust with low particle absorption is assumed. The difference in net radiative forcing between LGM and present day of $-2 \mathrm{~W} \mathrm{~m}^{-2}$ reduces to $-1 \mathrm{~W} \mathrm{~m}^{-2}$ if internal mixing of haematite aerosols with an upper limit for absorption is assumed. More recently, Takemura et al. (2009) simulated with an integrated aerosol-climate model the dust direct radiative forcing defined at the tropopause in all-sky conditions. The net forcing from summing up shortwave and longwave forcing is $-0.02 \mathrm{~W} \mathrm{~m}^{-2}$ for LGM climate and $-0.01 \mathrm{~W} \mathrm{~m}^{-2}$ for present climate, and the shortwave forcing only is $-0.24 \mathrm{~W} \mathrm{~m}^{-2}$ for LGM and $-0.10 \mathrm{~W} \mathrm{~m}^{-2}$ for present day. Mahowald et al. (2006b) find intermediate values of the net dust radiative forcing at TOA of -0.96 and $-1.47 \mathrm{~W} \mathrm{~m}^{-2}$ for the two LGM cases without and with glaciogenic dust sources, respectively, and $-0.87 \mathrm{~W} \mathrm{~m}^{-2}$ for preindustrial conditions.

Different possibilities might be responsible for the stronger negative dust radiative forcing obtained by Claquin 
et al. (2003) than by Takemura et al. (2009). Differences in radiative forcing could be caused by different optical parameters and the use of different shortwave schemes which impede a direct comparison. Claquin et al. (2003) used different single-scattering albedos for desert soils with different mineralogical composition. Takemura et al. (2009) accounted for size-dependent extinction coefficients (Takemura et al., 2002) and used a RI value for soil dust (see Appendix) based on recent studies (Takemura et al., 2005). The dust loads used for LGM and present day are larger by a factor of about 2.6 in Claquin et al. (2003) than in Takemura et al. (2009). The dust load in Claquin et al. (2003) for present day is $35.3 \mathrm{Tg}$, which is derived from the global dust emission flux of $3000 \mathrm{Tg} \mathrm{yr}^{-1}$ and the average lifetime of 4.3 days given in Mahowald et al. (1999). The smaller dust load of $13.6 \mathrm{Tg}$ in Takemura et al. (2009) results from a short dust lifetime of only 1.9 days although the emission flux of $2594 \mathrm{Tg} \mathrm{yr}^{-1}$ corresponds to $86 \%$ of the emission flux in Claquin et al. (2003). Their glacial dust emissions show compatible enhancement factors of 2.5 (Mahowald et al., 1999) and of 2.39 (Takemura et al., 2009). The stronger negative dust radiative forcing in Claquin et al. (2003) could further result from the longer dust lifetime whereby dust aerosols are transported farther downwind from source areas toward dark ocean areas. Hence, larger dust load and longer transport might contribute to the more negative forcing for LGM and present day in Claquin et al. (2003) than in Takemura et al. (2009).

Here, an Earth system model of intermediate complexity with coupled atmosphere, ocean, vegetation, ice sheet and dust cycle is used. Section 2 describes the climate model, the dust cycle model and the experimental design for the glacialinterglacial simulations. Section 3 presents model verifications and explores key parameters controlling the shortwave (SW) direct radiative forcing (DRF). Key parameters are the atmospheric dust lifetime and the imaginary refractive index of dust aerosols. Their ranges of uncertainty obtained from data and theoretical studies define a set of sensitivity experiments. Section 4 shows the results of the sensitivity simulations over glacial-interglacial climate changes. Implications of the parameter uncertainties are discussed with respect to uncertainties in DRF and with respect to uncertainties in the DRF-induced climate response. Conclusions are drawn in the final section, Sect. 5 .

\section{Model description}

\subsection{Climate model}

The present study uses an Earth system model of intermediate complexity (Claussen et al., 2002). The Earth system model CLIMBER-2 was tested in studies on the equilibrium climate sensitivity (Schneider von Deimling et al., 2006), on forced transient climate changes (Bauer et al., 2004, 2008; Brovkin et al., 2007; Calov et al., 2005; Ganopolski
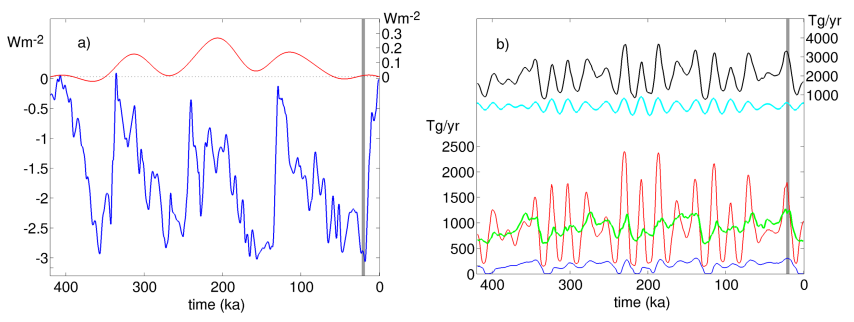

Figure 1. Forcing time series of climate model in $\mathrm{W} \mathrm{m}^{-2}$ (a) and simulated dust emission flux in $\mathrm{Tg} \mathrm{yr}^{-1}$ (b) for the past $420 \mathrm{kyr}$. (a) Annual global mean radiative forcing relative to present day from equivalent $\mathrm{CO}_{2}$ concentration (blue line) and orbitally varying insolation (red line). (b) Global dust emission flux of the total (black line) and of partitions from deserts (red line), grass areas (green line) and exposed shelf areas (blue line) compared to climatic precession parameter in arbitrary units (cyan line). Vertical grey bars mark LGM period over 23-19 ka.

and Roche, 2009) and on glacial-interglacial cycles (Bauer and Ganopolski, 2010; Bonelli et al., 2009; Ganopolski and Calov, 2011; Ganopolski et al., 2010).

The atmosphere model has a resolution of about $51^{\circ}$ in longitude and $10^{\circ}$ in latitude. The thermodynamical fields are vertically resolved on 10 levels and the longwave radiation transfer on 16 levels (Petoukhov et al., 2000; Ganopolski et al., 2001). The atmospheric fields of temperature, wind, precipitation and cloudiness are computed by a statisticaldynamical approach with a daily time step. The shortwave radiation transfer calculation uses the two-stream deltaEddington approximation (Shettle and Weinman, 1970) for wavelengths in the UV band $(0.2-0.4 \mu \mathrm{m})$ and visible band $(0.4-0.75 \mu \mathrm{m})$. The scheme includes molecular Rayleigh scattering, absorption by water vapor and carbon dioxide and effects of cloudiness. The ocean model describes the zonal-mean circulation in the three basins connected with the southern circum-polar circulation. The ocean model with a thermodynamic sea-ice model is integrated every five days. The vegetation model describes the cover of grass and forest on land surface grid cells by a function of growing degree days, precipitation and $\mathrm{CO}_{2}$ fertilization (Brovkin et al., 2002). The desert area results from the remaining fraction of the land surface without vegetation and ice cover. The shares of desert, vegetation and ice sheet on each land surface grid cell are computed with an annual time step, and the size of each land surface grid cell is given by the land-sea mask. The ice sheet model SICOPOLIS with a resolution of $1.5^{\circ}$ in longitude and $0.75^{\circ}$ in latitude simulates the ice sheet elevation in the Northern Hemisphere with a half-year time step (Greve, 1997; Calov et al., 2005). Ice sheet changes are fed back to calculations of the land-sea mask, the surface elevation, the freshwater flux and the surface albedo. The surface albedo is computed daily for each grid cell, accounting for land and ocean partitions, snow properties, clear and cloudy conditions and visible and infrared wavelength bands. 
The model is driven by orbitally varying insolation (Berger, 1978) and longwave greenhouse gas forcing from equivalent $\mathrm{CO}_{2}$ concentration using measurements of $\mathrm{CO}_{2}$, $\mathrm{CH}_{4}$ (methane) and $\mathrm{N}_{2} \mathrm{O}$ (nitrous oxide) from Antarctica (Petit et al., 1999; Augustin et al., 2004) as described in Ganopolski et al. (2010). Figure 1a shows the radiative energy fluxes from the sun and the greenhouse gases in terms of global and annual mean radiative forcing relative to preindustrial times $(0 \mathrm{kyr} B P=0 \mathrm{ka})$ for the past $420 \mathrm{kyr}$. The mean solar radiative forcing calculated with solar constant of $1360 \mathrm{~W} \mathrm{~m}^{-2}$ and mean planetary albedo of 0.3 varies only by up to $0.3 \mathrm{~W} \mathrm{~m}^{-2}$ with the periods of eccentricity of about 100 and $400 \mathrm{kyr}$. Here, short-term fluctuations from solar activity are neglected. Nevertheless, the seasonal and latitudinal distribution of insolation which varies strongly on orbital timescales constitutes a major driver for the glacial-interglacial climate changes. This is usually shown by the maximum insolation at $65^{\circ} \mathrm{N}$ in June (so-called Milankovitch forcing) which varies by more than $100 \mathrm{~W} \mathrm{~m}^{-2}$ on orbital timescales. In contrast, the long-term greenhouse gas forcing varies by up to $3 \mathrm{~W} \mathrm{~m}^{-2}$ and is nearly homogeneous with season and latitude.

\subsection{Dust cycle model}

The emission, transport and deposition of aeolian dust simulated by the dust cycle model are incorporated into the climate model (Bauer and Ganopolski, 2010). The long-term changes in the aeolian dust distribution result largely from changes in source areas. The terrestrial source areas comprise desert areas, semi-arid grass areas with sparse grass cover and shelf areas exposed after ice sheet growth from sea level decrease. The dust emission flux grows with the third power of the surface wind speed for speeds exceeding a threshold speed which is a function of soil dryness. The effect of wind gustiness (McGee et al., 2010) is implicitly included in the simulated surface winds. The surface winds account for baroclinity connected with meridional pressure gradients (Petoukhov et al., 2000), which are usually higher in glacial conditions. The dust uplift into the atmosphere depends on the static stability of the atmosphere.

The main constraint for adjusting the scaling parameters in the dust cycle model is to simultaneously reproduce the dust deposition fluxes reconstructed from DIRTMAP (Dust Indicators and Records of Terrestrial and MArine Palaeoenvironments) (Kohfeld and Harrison, 2001), from the tropical Pacific (Winckler et al., 2008) and from Antarctica (Augustin et al., 2004). Further constraints are provided by the AEROCOM (Aerosol Comparisons between Observations and Models) project (Textor et al., 2006). Accordingly, the simulated global and annual mean emission flux for present day is scaled to $1710 \mathrm{Tg} \mathrm{yr}^{-1}$ and the mean lifetime is adjusted to 4.7 days, giving a total load of $22.4 \mathrm{Tg}$ (Table 1). Thus, the present dust load per area of $43 \mathrm{mg} \mathrm{m}^{-2}$ is close to the median value of $39.1 \mathrm{mg} \mathrm{m}^{-2}$ obtained from the analysis of 20
Table 1. Simulated global dust emission flux, atmospheric dust load and lifetime for present day from three solutions of climate system model compared to other studies.

\begin{tabular}{lccc}
\hline & $\begin{array}{c}\text { Emission flux } \\
\left(\mathrm{Tg} \mathrm{yr}^{-1}\right)\end{array}$ & $\begin{array}{c}\text { Load } \\
(\mathrm{Tg})\end{array}$ & $\begin{array}{c}\text { Lifetime } \\
(\mathrm{d})\end{array}$ \\
\hline Solution L0 & 1710 & 22.4 & 4.7 \\
Solution L1 & 1710 & 27.2 & 5.7 \\
Solution L2 & 1710 & 17.2 & 3.6 \\
\hline Mahowald et al. (1999) & 3000 & 35.3 & 4.3 \\
Mahowald et al. (2006a), & 8040 & 59.5 & 2.7 \\
Mahowald et al. (2006b)* & & & \\
Takemura et al. (2009) & 2594 & 13.6 & 1.9 \\
Textor et al. (2007) (Exp B) & 1630 & 21.3 & 4.8 \\
\hline
\end{tabular}

* Simulation with $\mathrm{CO}_{2}$ fertilization for preindustrial conditions.

Table 2. Global dust deposition flux and dust load per area from three solutions of climate system model simulated at $21 \mathrm{ka}$ (LGM) and $0 \mathrm{ka}$ (PRE).

\begin{tabular}{lccrc}
\hline \multirow{2}{*}{ Solution } & \multicolumn{2}{c}{ Deposition flux $\left(\mathrm{Tg} \mathrm{yr}^{-1}\right)$} & \multicolumn{2}{c}{ Dust load $\left(\mathrm{mg} \mathrm{m}^{-2}\right)$} \\
& LGM & PRE & LGM & PRE \\
\hline L0 & 3220 & 1710 & 83.3 & 43.9 \\
L1 & 3220 & 1710 & 101.8 & 53.3 \\
L2 & 3220 & 1710 & 63.5 & 33.7 \\
\hline
\end{tabular}

different global circulation models (Kinne et al., 2006). For LGM climate, the dust cycle model produces a dust emission flux of $3220 \mathrm{Tg} \mathrm{yr}^{-1}$, which is a factor of 1.88 larger than for present day. The corresponding dust load is equally increased because the mean lifetime changes hardly during the glacial cycle simulation (Table 2 ).

Figure $1 \mathrm{~b}$ shows the time series of the global dust emission flux over $420 \mathrm{kyr}$ together with the individual contributions from deserts, grass areas and exposed shelf areas. The total dust emission flux varies primarily with the source areas located in the Sahara and in Arabia followed by areas in Asia, North and South America, Australia and southern Africa. The Sahara is suggested to vary periodically through climate-vegetation feedbacks driven by insolation changes (Ganopolski et al., 1998). The dust emission (Fig. 1b) correlates with the climatic precession parameter defined by the longitude of perihelion and the orbital eccentricity (Berger et al., 1993). Maxima in dust emission follow minima in daily irradiation at summer solstice in the Northern Hemisphere. The omnipresent portion of dust emitted from grass areas fluctuates with the atmospheric $\mathrm{CO}_{2}$ concentration due to the $\mathrm{CO}_{2}$ fertilization effect on vegetation growth. The dust emission from exposed shelf areas is small and proportional to the volume of the glacial inland ice. Note that glaciogenic dust is not considered in the present emission scheme. 

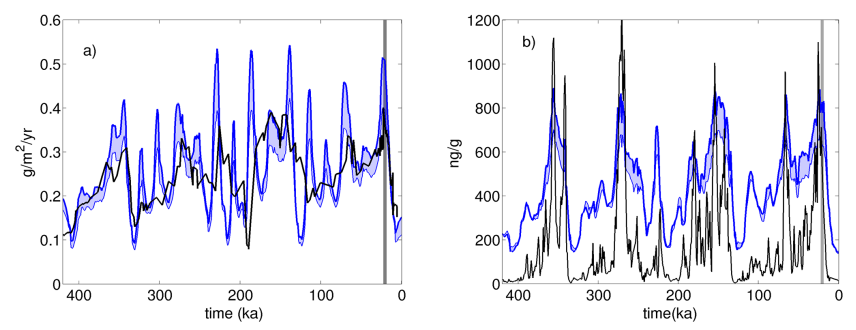

Figure 2. Time series of regional dust deposition for the past $420 \mathrm{kyr}$. (a) Simulated range of dust deposition (blue shaded) from solutions L1 with a high dust lifetime (thick line) and L2 with a low dust lifetime (thin line) for the equatorial Pacific in $\mathrm{g} \mathrm{m}^{-2} \mathrm{yr}^{-1}$ compared to data (black line) from Winckler et al. (2008). (b) As in (a) but for dust concentration $\left(\mathrm{ng} \mathrm{g}^{-1}\right.$ ) in Antarctic ice compared to data from Augustin et al. (2004). Vertical grey bars as in Fig. 1.

\subsection{Experimental design}

The sensitivity experiments are conducted over the last eight glacial cycles. They are forced by insolation and greenhouse gases as shown in Fig. 1a for the last 420 kyr. The dust deposition on ice and snow surfaces is simulated using the dust deposition fields for LGM and present day from Mahowald et al. (1999) as described in Calov et al. (2005) and used previously (Bauer and Ganopolski, 2010; Ganopolski et al., 2010). Unlike in our previous studies, the dust DRF is now simulated interactively in a consistent manner with the dust cycle model and the SW radiation scheme. The previous workaround of using external simulations for dust DRF (indicated by RDST in Fig. 1 of Ganopolski et al. (2010)) is found to have a minor effect and is not further used. Thus the control simulation in the present study is without dust DRF.

The following sensitivity experiments investigate causes of uncertainties in dust DRF and the resulting response in the climate system. Uncertainties in SW DRF by aeolian dust during glacial cycles are mainly caused by uncertainties in atmospheric dust load and uncertainties in scattering and absorption effects by aeolian dust. The SW DRF represents the instantaneous change in the SW radiative flux defined at TOA. The dust DRF is calculated from two runs of the SW radiation scheme with and without atmospheric dust load while the climate fields in both runs are identical (Woodward, 2001). Here, indirect effects from interactions between dust aerosols and clouds and longwave effects are not considered.

\section{Model verification}

The model verification addresses the uncertainty in the climate-driven atmospheric dust load and the uncertainty in the optical parameter describing the scattering and absorption effect by aeolian dust. The key parameters are the atmospheric dust lifetime and the imaginary RI (see Appendix). Section 3.1 describes the determination of high and low boundaries for dust load. Then Sect. 3.2 tests the calculation of dust SW DRF by comparing the simulated dust DRF as a function of surface albedo, RI and cloudiness with theoretical and data studies.

\subsection{Dust load}

The geographic distribution of the atmospheric dust load depends on dry and wet deposition processes apart from emission and transport processes. General circulation models, which account for the aerosol size distribution, simulate an increasing dry deposition flux for increasing sizes. The fraction of wet deposition flux relative to the total deposition flux ranges from $48 \%$ (Luo et al., 2003) to $16 \%$ (Liao et al., 2004). The scavenging of particles by precipitation is a complex micro-physical process and a description requires physical and chemical information on the aerosols. Here, the dry and wet deposition fluxes depend on the dust load in each atmospheric column. The two scaling parameters for gravitationally driven dry deposition and precipitation-driven wet deposition were determined by assuming that the dry and wet deposition fluxes are equal on average (Bauer and Ganopolski, 2010). If this ad hoc assumption for the initial solution (L0) is released, then by varying the scaling parameters two other reasonable solutions (L1, L2) are found. These solutions may be seen concurrent to the initial solution, because their simulated depositions agree likewise with reconstructions from the tropical Pacific (Fig. 2a) and from Antarctic ice cores (Fig. 2b) over the past $420 \mathrm{kyr}$. In solution L1, the fraction of wet deposition flux is $70 \%$ of the total and is $6 \%$ in solution L2. The dust deposition flux over Asia is slightly larger in L1 than in L2, but both solutions agree with the DIRTMAP data (Kohfeld and Harrison, 2001) within uncertainty ranges.

The solutions L1 and L2 differ by their total atmospheric loads (Table 2) attributed to different lifetimes. In solution L1, in which wet deposition dominates dry deposition, the present-day dust load is $27.2 \mathrm{Tg}$ and the lifetime is $5.7 \mathrm{~d}$, while the reversed dominance in solution L2 results in a load of $17.2 \mathrm{Tg}$ and a lifetime of $3.6 \mathrm{~d}$. The high and low dust loads in solutions L1 and L2, respectively, are still within the range simulated with general circulation models (Table 1).

The geographic dust distributions from the three solutions show peak values over the source areas in northern Africa and Asia as displayed for LGM and present day from solution L1 (Fig. 3a, b). Differences in dust load between LGM and present day in solution L1 reach regionally about $500 \mathrm{mg} \mathrm{m}^{-2}$ (Fig. 3c). The largest differences are over Africa, Asia, the subtropical North Atlantic and the subtropical latitudes of South America and Australia. The dust load differences between solution $\mathrm{L} 1$ relative to solution $\mathrm{L} 2$ show a maximum around $500 \mathrm{mg} \mathrm{m}^{-2}$ over the Sahara at LGM (Fig. 3d). Nonetheless, the deposition fluxes in solutions L1 and $\mathrm{L} 2$ agree reasonable with data (Fig. 2a, b). This is accomplished through the larger wet deposition in L1 than in 

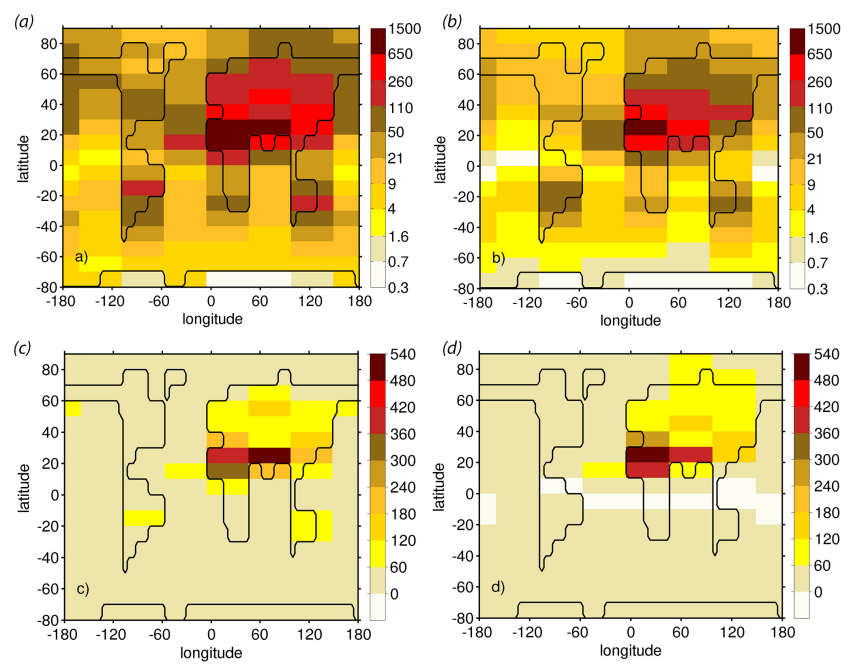

Figure 3. Geographic distributions of atmospheric dust load $\left(\mathrm{mg} \mathrm{m}^{-2}\right)$ from solution L1 for $21 \mathrm{ka} \mathrm{(a)} \mathrm{and} 0 \mathrm{ka}$ (b) with a logarithmic scale. Difference distributions of dust load shown with a linear scale for $21 \mathrm{ka}$ relative to $0 \mathrm{ka}$ from solution $\mathrm{L} 1$ (c) and from solution L1 relative to solution L2 for $21 \mathrm{ka}(\mathbf{d})$.

L2, which implies more dust removal in the tropical rain belt (i.e. tropical Pacific) and longer dust suspension in air over dry areas in L1 than in L2. The prolonged westward transport of Saharan dust to the Atlantic Ocean by trade winds in $\mathrm{L} 1$ is partly compensated by larger wet deposition over ocean than over land. Dust deposits in Antarctica originate mainly from South America and to a lesser extent from Australia, which implies a long-range transport over the Southern Ocean. So, to reasonably reproduce the dust deposition far away from source areas, a larger fraction of wet deposition calls for a longer dust lifetime.

\subsection{Dust SW DRF}

The dust SW DRF is a nonlinear function of daily insolation, solar zenith angle, dust AOT, dust RI (see Appendix), surface albedo and cloudiness. In practice, the vertical integral of the simulated dust mass distribution can be converted into the dust AOT distribution by use of an effective parameter for dust mass extinction. Measurements show (Sow et al., 2009) that the size distribution of aeolian dust particles uplifted by convective events is fairly constant and relatively insensitive to surface wind variations. If these results from the African Monsoon Multidisciplinary Analysis (AMMA) project can be seen as representative also for other regions and wind conditions, then some support is given for assuming that dust particles can be aggregated into a single bin. It then seems justified for the present study to determine dust AOT as a function of dust mass load by use of the dust mass extinction efficiency (ME) available from the AEROCOM study (Kinne et al., 2006).
For present day, median values are for dust dry mass per area $39.1 \mathrm{mg} \mathrm{m}^{-2}$, for dust AOT at a wavelength of $0.55 \mu \mathrm{m}$ 0.032 and for dust ME $0.95 \mathrm{~m}^{2} \mathrm{~g}^{-1}$ (Kinne et al., 2006). For comparison, the simulated mean dust AOT of 0.053 at a wavelength $0.5 \mu \mathrm{m}$ for the current climate (Mahowald et al., 2006b) ranks at the upper limit of diversity discussed in Kinne et al. (2006). Here, $\mathrm{ME}=0.95 \mathrm{~m}^{2} \mathrm{~g}^{-1}$ is used for reasons of simplicity and because possible variations in dust ME associated with different types of dust sources are poorly known. Also, the AEROCOM project provides a mean estimate of $\mathrm{RI}=0.0015$ at mid-visible wavelength (Kinne et al., 2006). Various investigations suggest an uncertainty range for dust RI from 0.0005 to 0.0060 (Dubovik et al., 2002), which is considered in the following sensitivity simulations.

Theoretical studies show that the DRF at TOA induced by mineral dust aerosols divides into three regimes, a regime with negative forcing occurring over dark ocean surfaces, a regime with positive forcing occurring over bright snow and ice surfaces and a transition regime in which the sign of the radiative forcing changes (Liao and Seinfeld, 1998). The larger the particle number concentration per volume of air and the lower the surface albedo are, the larger is the backscatter of the insolation at TOA. Otherwise, the larger the particle number concentration and the larger the surface albedo are, the more light is absorbed owing to multiple reflections between the aerosols and the surface whereby the dust DRF at TOA can achieve positive values. The DRF at TOA changes its sign at the critical surface albedo, which varies with AOT, RI and cloudiness.

A consequence of the absorption and scattering effects by aerosols is that the SW radiative forcing at the surface is always negative and gets increasingly negative with increasing extinction of the insolation. The reduction of insolation at the surface is connected with a gain of radiative energy in the atmosphere. Here, the calculations of Liao and Seinfeld (1998) of dust DRF at TOA and at the surface for clear and cloudy sky with a one-dimensional radiative transfer model based on Mie's theory are used to validate the SW scheme of the climate model (Petoukhov et al., 2000).

Figure 4a shows the simulated dust DRF as a function of surface albedo for a dust load of $100 \mathrm{mg} \mathrm{m}^{-2}$ as used by Liao and Seinfeld (1998). The dust DRF at TOA and at the surface are shown for cloud-free conditions and for a typical mean cloud fraction of 0.6. The sensitivity of the dust DRF is displayed for RI of 0.001 and 0.006 by shaded areas. The boundaries of the shaded areas obtained with $\mathrm{RI}=0.006$ are directly comparable with the calculations of Liao and Seinfeld (1998). Their DRF at TOA and at the surface are closely reproduced for clear sky. For the partially cloudy sky, the simulated TOA and surface DRF vary over a slightly larger range than in Liao and Seinfeld (1998). This is presumably due to the partial cloud fraction used in our simulations since the SW DRF diminishes gradually with growing cloudiness.

The critical surface albedo for DRF at TOA with RI= 0.006 is close to the surface albedo for the Sahara of 0.3-0.35 

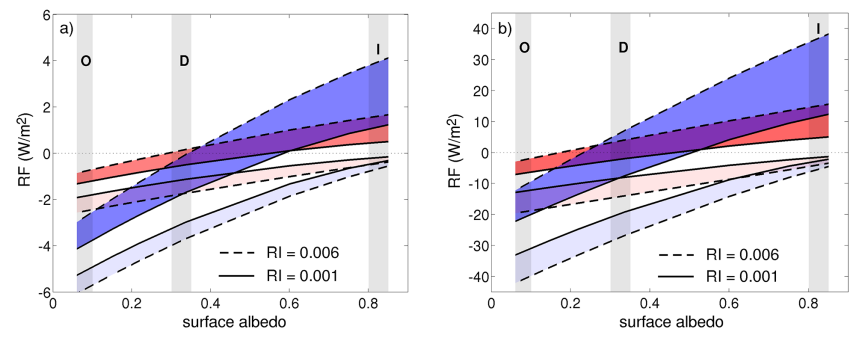

Figure 4. Dust SW DRF as a function of surface albedo simulated for dust load $100 \mathrm{mg} \mathrm{m}^{-2}$ (a) and $1000 \mathrm{mg} \mathrm{m}^{-2}$ (b). DRF at TOA (dark shading) and DRF at surface (light shading) for clear sky (blue shading) and for mean cloud fraction of 0.6 (red shading) where boundaries of shaded areas are obtained with $\mathrm{RI}=0.001$ and $\mathrm{RI}=$ 0.006 . Vertical grey bars show surface albedo typical for ocean, the Sahara and ice/snow marked with O, D and I, respectively.

in clear and cloudy conditions for a dust load of $100 \mathrm{mg} \mathrm{m}^{-2}$ (Fig. 4a). In contrast, the critical surface albedo is about 0.6 with $\mathrm{RI}=0.001$ in clear and cloudy conditions, which implies a negative DRF at TOA over the Sahara. However, the dust load over deserts and in particular during glacial periods often exceeds $100 \mathrm{mg} \mathrm{m}^{-2}$, and Fig. $4 \mathrm{~b}$ shows the dust DRF for $1000 \mathrm{mg} \mathrm{m}^{-2}$. The DRF increases by a factor of 8 to 10 for the 10 -fold increase in dust load, and the critical surface albedo shifts to smaller values with increasing dust load. This means that a dust load of $1000 \mathrm{mg} \mathrm{m}^{-2}$ over a cloudless Sahara leads to a positive TOA forcing between 5 and $8 \mathrm{~W} \mathrm{~m}^{-2}$ for $\mathrm{RI}=0.006$ and to a negative TOA forcing between -11 and $-9 \mathrm{~W} \mathrm{~m}^{-2}$ for $\mathrm{RI}=0.001$. Hence Fig. $4 \mathrm{~b}$ suggests that dust DRF at TOA can be small for a large dust load over a bright desert area with RI between 0.001 and 0.006. At the surface, the SW DRF is negative for all values of dust load and surface albedo and gets increasingly negative with increasing extinction of the insolation in the atmosphere (Fig. 4).

Simulations of dust DRF are difficult to verify because the provision of adequate data is hindered by the interactions among aerosols, radiation and cloudiness. In clear-sky conditions, the simulated dust DRF can be assessed with satellitebased estimates on dust DRF. Measurements of SW DRF at TOA in clear-sky conditions over the Atlantic Ocean between 0 and $30^{\circ} \mathrm{N}$ can be ascribed to the abundant dust aerosols for which the forcing is estimated to be $-7.75 \pm 0.86 \mathrm{~W} \mathrm{~m}^{-2}$ (Christopher and Jones, 2007). This estimate is obtained for dust AOT at a wavelength $0.55 \mu \mathrm{m}$ during the months June to August in the years 2000 to 2005 . The longwave dust forcing is positive and cancels nearly $20 \%$ of the negative SW DRF, resulting in a net radiative forcing of $-6.31 \pm 1.16 \mathrm{~W} \mathrm{~m}^{-2}$ (Christopher and Jones, 2007). The mean direct radiative effect at TOA for one year (2000-2001) over global land areas in clear-sky conditions is found to be $-5.1 \pm 1.15 \mathrm{~W} \mathrm{~m}^{-2}$ (Patadia et al., 2008). This estimate is obtained for AOT at a wavelength of $0.558 \mu \mathrm{m}$, including contributions from differ-
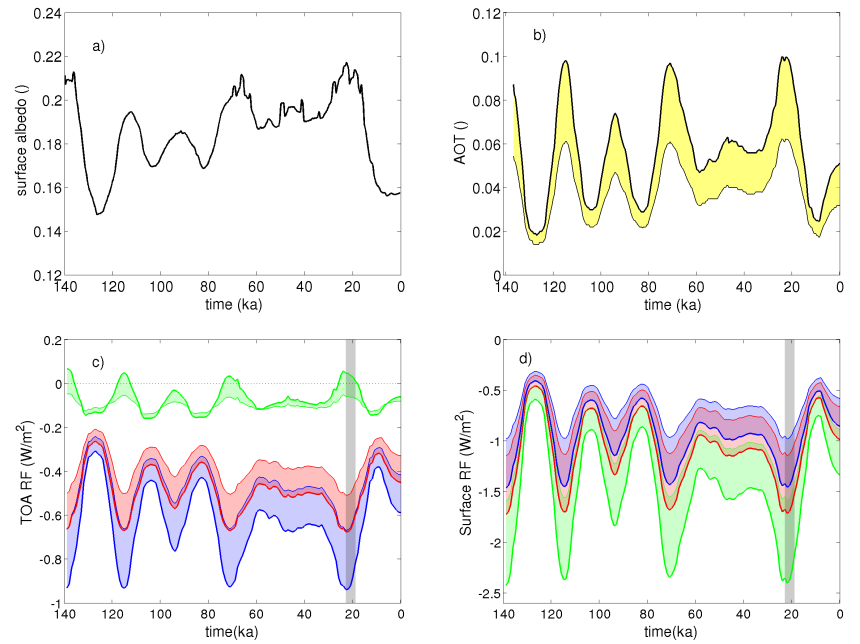

Figure 5. Time series of annual global mean surface albedo (a), dust AOT (b) and dust SW DRF ( $\mathrm{W} \mathrm{m}^{-2}$ ) at TOA (c) and at surface (d) for last $140 \mathrm{kyr}$. (b) Range of dust AOT (yellow shaded) from solutions L1 (thick line) and L2 (thin line), respectively. (c) and (d) DRF from six simulation experiments using dust AOT from L1 and L2 (line width as in (b) and RI = 0.0005 (blue shaded), 0.0015 (red shaded) and 0.0060 (green shaded). Vertical grey bars as in Fig. 1.

ent natural and anthropogenic aerosols but excluding aerosol loads over regions with high surface reflectance. A detailed analysis for the Sahara with a surface albedo $0.35-0.40$ shows that the SW DRF at TOA is small and nearly insensitive to increasing AOT (Patadia et al., 2009; Yang et al., 2009). That low sensitivity derived from satellite data and supported by four-stream radiative transfer calculations for clear sky is reasonably well reproduced by the SW scheme of our climate model.

\section{Simulation experiments over glacial cycle}

The effect of uncertainties in the parameters describing the dust SW DRF is tested in transient simulations and presented for the last glacial-interglacial climate cycle. We show six simulation experiments using an upper and a lower value for dust lifetime and for both cases three different absorption efficiencies. The high and low values for dust lifetime are obtained from solutions L1 and L2 of the dust cycle model (see Sect. 3.1), and low, medium and high absorption efficiencies are described by RI values of $0.0005,0.0015$ and 0.0060 , respectively (see Sect. 3.2).

\subsection{Analysis of dust DRF}

The different dust lifetimes in solutions L1 and L2 yield the potential range of the annual and global mean dust AOT, which is shown Fig. $5 \mathrm{~b}$ for the last $140 \mathrm{kyr}$. The dust AOT in solution L1 varies between about 0.02 and 0.10 , and in solution $\mathrm{L} 2$ between about 0.015 and 0.060 . The dust AOT varies 
Table 3. Global mean dust AOT and dust DRF at TOA from six simulations using solutions L1 and L2 and low, medium and high imaginary refractive index (RI) calculated at $21 \mathrm{ka}(\mathrm{LGM})$ and $0 \mathrm{ka}$ (PRE).

\begin{tabular}{lccccc}
\hline \multicolumn{2}{c}{ Experiment } & \multicolumn{2}{c}{ Dust AOT () } & \multicolumn{2}{c}{ Dust DRF $\left(\mathrm{W} \mathrm{m}^{-2}\right)$} \\
Solution & RI & LGM & PRE & LGM & PRE \\
\hline L1 & 0.0005 & 0.097 & 0.051 & -0.92 & -0.59 \\
L2 & 0.0005 & 0.060 & 0.032 & -0.65 & -0.42 \\
L1 & 0.0015 & 0.097 & 0.051 & -0.66 & -0.45 \\
L2 & 0.0015 & 0.060 & 0.032 & -0.50 & -0.33 \\
L1 & 0.0060 & 0.097 & 0.051 & +0.04 & -0.06 \\
L2 & 0.0060 & 0.060 & 0.032 & -0.06 & -0.08 \\
\hline
\end{tabular}

with the period of climatic precession in correspondence to the dust emission flux (Fig. 1b). The dust AOT shows a peak value at the beginning of the LGM period, which is defined from 23 to $19 \mathrm{ka}$ (Waelbroeck et al., 2009), and a minimum value in the early Holocene at $9 \mathrm{ka}$ when a large fraction of the Sahara is simulated with grass cover. The simulated range of dust AOT for present-day (preindustrial) climate of 0.032-0.051 (Table 3) lies well in the interval 0.012-0.054 obtained from models participating in the AEROCOM exercise (Kinne et al., 2006). Dust AOT and surface albedo are correlated and AOT maxima concur with enhanced surface albedo from increased snow and ice cover in cold periods (Fig. 5a).

The annual and global means of dust DRF at TOA from the six simulation experiments (Fig. 5c) vary with the period of climatic precession as dust AOT. The dust DRF calculated for the three RI values is displayed by three shaded bands of which the boundaries result from high and low lifetimes corresponding to high and low AOT. The dust DRF obtained with RI of 0.0005 and 0.0015 is negative and correlated with dust AOT. This is different when RI $=0.0060$ is used. The dust DRF from L1 with high lifetime fluctuates around zero with positive values for large dust AOT, and the dust DRF from L2 with low lifetime is negative and anticorrelated with dust AOT. The strongest negative DRF of $-0.92 \mathrm{~W} \mathrm{~m}^{-2}$ at $21 \mathrm{ka}$ and $-0.59 \mathrm{~W} \mathrm{~m}^{-2}$ at $0 \mathrm{ka}$ is obtained in the experiment with low absorption efficiency and high dust AOT (Table 3).

At the surface, the dust DRF is negative and its strength increases with dust AOT and absorption efficiency (Fig. 5d). The surface radiative forcing obtained from the six experiments range from -0.95 to $-2.4 \mathrm{~W} \mathrm{~m}^{-2}$ for LGM climate and from -0.6 to $-1.35 \mathrm{~W} \mathrm{~m}^{-2}$ for present-day climate. These ranges of the surface radiative forcing enclose the values presented in Mahowald et al. (2006b), which are -1.28 and $-1.59 \mathrm{~W} \mathrm{~m}^{-2}$ for two LGM cases and $-1.03 \mathrm{~W} \mathrm{~m}^{-2}$ for the preindustrial case.

The annual zonal means of dust AOT show the largest values in the latitudes with the major dust sources. These are in the latitude band $20-30^{\circ} \mathrm{N}$ for both solutions and at both periods 21 and $0 \mathrm{ka}$ (Fig. 6a and b). The dust DRF at TOA from
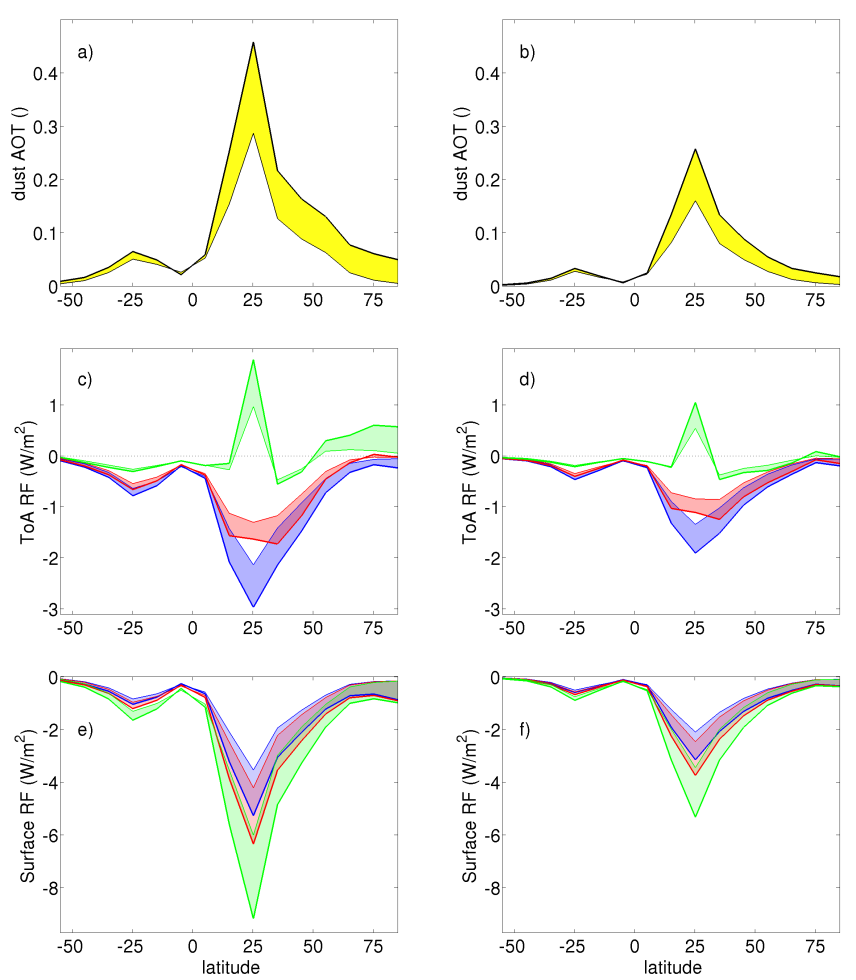

Figure 6. Zonal means from simulations for dust AOT (a, b), DRF $\left(\mathrm{W} \mathrm{m}^{-2}\right)$ at TOA (c, d) and DRF at surface (e, f) for $21 \mathrm{ka}(\mathbf{a}, \mathbf{c}, \mathbf{e})$ and $0 \mathrm{ka}(\mathbf{b}, \mathbf{d}, \mathbf{f})$. Colour shading and line width as in Fig. 5.

the six sensitivity experiments is seen to be substantial in the northern subtropical latitudes and at the same time highly uncertain (Fig. 6c and d). In the latitude band of maximum dust load, the dust DRF is either negative or positive when using the low or high absorption efficiency, respectively. This is most obvious for LGM conditions when the dust DRF from solution $\mathrm{L} 1$ changes from about -3 to $+2 \mathrm{~W} \mathrm{~m}^{-2}$ with RI growing from 0.0005 to 0.0060 (Fig. 6c). The experiment with medium absorption efficiency leads to a negative DRF for both solutions and periods; however, the sensitivity of dust DRF on dust load in the northern subtropical latitude band is reduced because the surface albedo of the Sahara is close to the critical value (Fig. 4).

The dust DRF at the surface concentrates in northern subtropics (Fig. 6e and f) owing to the localized dust load. The larger the absorption of the insolation by atmospheric dust is, the stronger is the decrease of solar radiation energy at the surface and the gain of radiative energy in the atmosphere above. For LGM conditions, the surface DRF in the subtropics increases from about -3.5 up to $-9.3 \mathrm{~W} \mathrm{~m}^{-2}$ with RI growing from 0.0005 to 0.0060 .

Figure 7 shows the geographically varying annual mean dust DRF at TOA for solution L1 with medium absorption efficiency for LGM and present day. For LGM climate (Fig. 7a), the dust DRF in the grid cell east of the Sahara is stronger than $-6 \mathrm{Wm}^{-2}$, north and south of the Sahara 

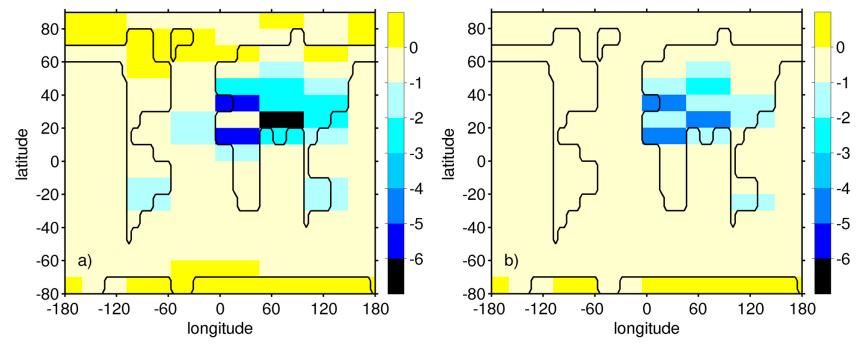

Figure 7. Geographic distributions of dust SW DRF at TOA $\left(\mathrm{W} \mathrm{m}^{-2}\right.$ ) with dust load of solution $\mathrm{L} 1$ and $\mathrm{RI}=0.0015$ for $21 \mathrm{ka}$ (a) and $0 \mathrm{ka}$ (b).

stronger than $-5 \mathrm{~W} \mathrm{~m}^{-2}$ and over large areas of Asia between -2 and $-3 \mathrm{Wm}^{-2}$. In northern low latitudes of the Atlantic and subtropical latitudes of South America and Australia the DRF is between -1 and $-2 \mathrm{~W} \mathrm{~m}^{-2}$. In high latitudes with snow or ice cover the dust DRF reaches small positive values. For present-day climate (Fig. 7b), the dust DRF is negative and concentrated over northern Africa, southern Europe and Asia. The strongest negative DRF of about $-4 \mathrm{~W} \mathrm{~m}^{-2}$ occurs over land adjacent to the Sahara grid cell with maximum dust load. The maps of dust DRF (Fig. 7) compare reasonably with the maps of net dust radiative forcing shown in Takemura et al. (2009) except for the positive forcing over the Sahara in Takemura et al. (2009). That positive forcing results presumably from the longwave forcing which can outbalance the negative shortwave forcing in the net forcing.

\subsection{Analysis of climate response to dust DRF}

The dust DRF at TOA can alter the global energy budget and thereby change the annual and global mean near-surface air temperature (SAT). Deviations from proportionality between forcing and SAT change can occur through interaction processes in the climate system comprising dynamic components with different response timescales. Simulated climate variables contain millennium-scale variability leading to variability on multi-millennia scales in anomaly series. Figure 8 shows the response of specific climate variables smoothed by a $1000 \mathrm{yr}$ running mean for the last $140 \mathrm{kyr}$ as obtained by the six simulation experiments.

Figure 8a compares the glacial-interglacial SAT evolution of the control simulation without DRF with the upper and lower bounds resulting from the DRF-driven simulation experiments. The simulation experiment with L1 and $\mathrm{RI}=0.0060$ has the least effect on SAT and agrees closely with the control simulation which shows a cooling by $5.3 \mathrm{~K}$ at LGM relative to present day. The simulation experiment with $\mathrm{L} 1$ and $\mathrm{RI}=0.0005$ produces the strongest effect and causes a SAT cooling relative to the control simulation of about $1.1 \mathrm{~K}$ at present day and of $2.3 \mathrm{~K}$ at LGM. In that experiment, SAT cools by $6.5 \mathrm{~K}$ at LGM relative to present
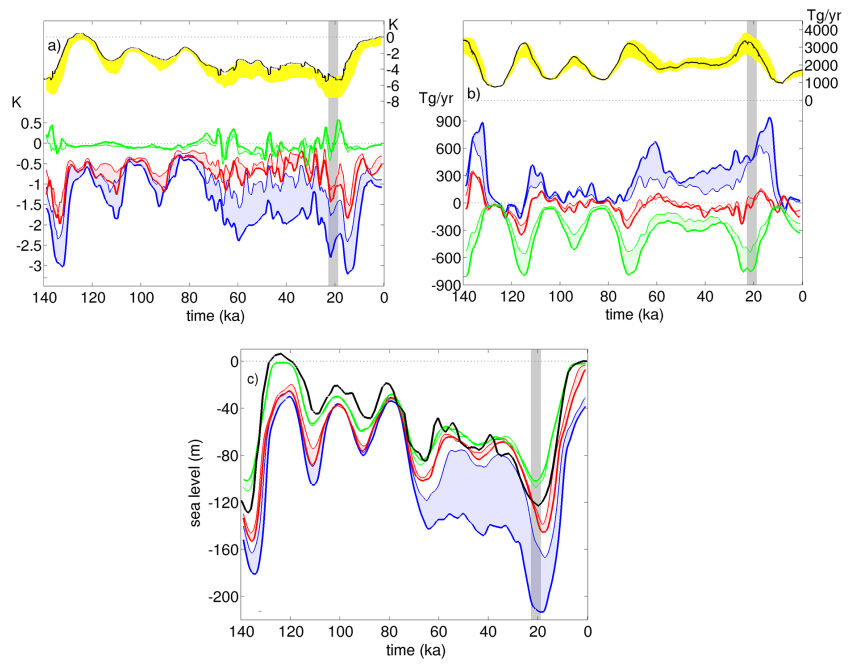

Figure 8. Response to dust DRF from simulation experiments for last $140 \mathrm{kyr}$. (a) Global SAT (K) of control simulation minus present-day SAT (black line) and range from upper and lower SAT (yellow shaded) from simulations with solution L1 and RI = 0.0005 and 0.0060 , and lower graphs show SAT anomaly series (K) from six simulation experiments minus control SAT series for $\mathrm{RI}=0.0005,0.0015$ and 0.0060 (colour shading and line width as in Fig. 5). (b) Total dust emission flux $\left(\mathrm{Tg} \mathrm{yr}^{-1}\right)$ of control simulation (black line) and range from upper and lower emission fluxes (yellow shaded) as in (a), and lower graphs show dust emission flux anomalies $\left(\mathrm{Tg} \mathrm{yr}^{-1}\right)$ as in (a). (c) Sea level (m) from simulations (colour shading and line width as in (a) compared to data (black line) of Waelbroeck et al. (2002). Vertical grey bars as in Fig. 1.

day. In general, the SAT cooling due to SW DRF by atmospheric dust relative to the control simulation increases with increasing dust load and with decreasing absorption efficiency for RI from 0.0015 to 0.0005 (Fig. 8a). The maximum SAT cooling of more than $-3 \mathrm{~K}$ with high dust load in solution L1 and RI $=0.0005$ occurs around $16 \mathrm{ka}$ and shows that the glacial cooling is amplified and prolonged involving a delayed transition to Holocene climate. This is different in the DRF-driven simulation experiment with $\mathrm{RI}=0.0060$ in which the amplitudes of SAT anomalies vary by only $0.5 \mathrm{~K}$.

The dust DRF affects temperature and precipitation, which in turn affect the dust source strength and thus dust AOT, which either amplify or attenuate the instantaneous dust DRF in the climate system (Table 4). Fig. 8b shows the dust emission flux from the control simulation and the induced upper and lower bounds obtained from the simulations experiments with solution L1 and low and high absorption efficiencies, respectively. At LGM, the dust emission flux is $3400 \mathrm{Tg} \mathrm{yr}^{-1}$ in the control simulation and ranges from 2400 to $3900 \mathrm{Tg} \mathrm{yr}^{-1}$ in the DRF-driven simulation experiments. The anomaly series of the total dust emission flux from the six simulations experiments relative to the control simulation are insignificantly small in the early Holocene and the Eemian period around $125 \mathrm{ka}$ but are substantial during 
Table 4. Impact of dust DRF on global dust emission flux and dust AOT from six simulation experiments using solutions L1 and L2 and low, medium and high imaginary refractive index (RI) calculated at $21 \mathrm{ka}(\mathrm{LGM})$ and $0 \mathrm{ka}(\mathrm{PRE})$.

\begin{tabular}{lccccc}
\hline \multicolumn{2}{c}{ Experiment } & \multicolumn{2}{c}{ Emission flux $\left(\mathrm{Tg} \mathrm{yr}^{-1}\right)$} & \multicolumn{2}{c}{ Dust $\mathrm{AOT}()$} \\
Solution & RI & LGM & PRE & LGM & PRE \\
\hline L1 & 0.0005 & 3650 & 1730 & 0.116 & 0.050 \\
L2 & 0.0005 & 3690 & 1740 & 0.070 & 0.032 \\
L1 & 0.0015 & 3110 & 1600 & 0.096 & 0.047 \\
L2 & 0.0015 & 3260 & 1640 & 0.061 & 0.031 \\
L1 & 0.0060 & 2450 & 1380 & 0.072 & 0.040 \\
L2 & 0.0060 & 2710 & 1480 & 0.051 & 0.028 \\
\hline
\end{tabular}

glacial conditions (Fig. 8b). Using solution L1, the emission flux increases by more than $900 \mathrm{Tg} \mathrm{yr}^{-1}$ with the low absorption efficiency and decreases by up to $800 \mathrm{Tg}^{-1} \mathrm{r}^{-1}$ with the high absorption efficiency. Thus changes in dust absorption efficiency lead to climate changes and in turn to dust emission changes. Using $\mathrm{RI}=0.0060$ leads to a decreased emission flux from shrinking desert areas in Africa, northward extending grass areas in Asia and from reducing the uplift of dust into the atmosphere. In contrast, the use of $\mathrm{RI}=0.0005$ leads to an increased emission flux attributed to increased desert areas, reduced grass cover and increased shelf areas from growing inland ice volume. The experiments conducted with $\mathrm{RI}=0.0015$, which give glacial-interglacial variations in dust DRF from -0.7 to $-0.2 \mathrm{~W} \mathrm{~m}^{-2}$ (Fig. 5c), produce fluctuating anomalies in the dust emission fluxes with amplitudes up to $300 \mathrm{Tg} \mathrm{gr}^{-1}$.

An independent measure to assess the output of the DRFdriven simulations is the comparison of the simulated ice volume with sea level reconstructions (Waelbroeck et al., 2002) shown in Fig. 8c. The simulated ice volume is seen to respond to the dust DRF (Fig. 5c) with some time delay. The simulated ice volume with high absorption efficiency matches the ice volume of the control simulation which reproduces the reconstruction closely and underestimates the observed sea level drop at LGM only slightly. The ice volume simulated with medium absorption efficiency is larger than reconstructed from the Eemian period toward LGM and agrees closely with the reconstruction at LGM. Then until about $18 \mathrm{ka}$, the simulated ice volume grows further and reaches the low value of the Holocene with about a $10 \mathrm{kyr}$ delay. The simulations with low absorption efficiency produce a more strongly growing ice volume after $70 \mathrm{ka}$ than the simulations with medium RI. Then toward the glacial maximum the sea level with a low dust load in solution L2 dropped to about $-160 \mathrm{~m}$ and with a high dust load in solution L1 to about $-210 \mathrm{~m}$. Thus, the negative dust DRF obtained with $\mathrm{RI}=0.0005$ drives a positive feedback loop. The negative DRF grows through the increasing dust emissions from cooler and dryer climate conditions and the amplified growth in ice volume in the time interval 70-18 ka. Inversely,
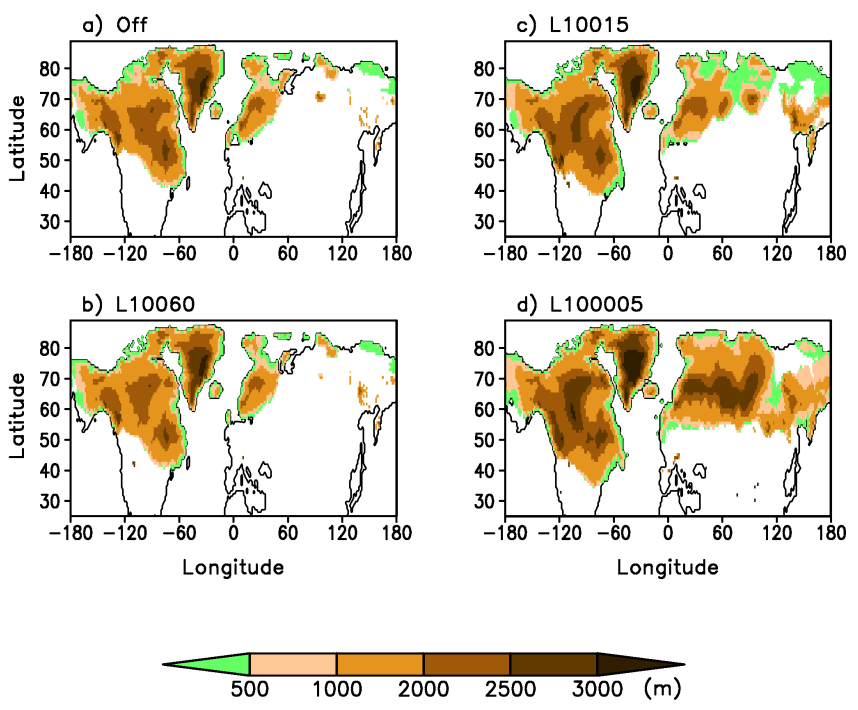

Figure 9. Simulated ice sheet extent and elevation (m) at LGM in control simulation without radiative forcing by atmospheric dust (a), and experiments using solution L1 with $\mathrm{RI}=0.0060$ (b), RI = 0.0015 (c) and $\mathrm{RI}=0.0005$ (d).

the positive DRF obtained with high absorption efficiency is connected with a negative feedback loop which leads to warming, eventually to ice melt and sea level rise and in turn to less dust emission.

The DRF-induced effect on the ice sheet distribution with $\mathrm{RI}=0.0060$ at LGM compared to the control simulation shows slightly reduced ice sheets in Europe and North America, similar to that simulated in Ganopolski et al. (2010). In the simulation with $\mathrm{RI}=0.0015$, the North American ice sheet is only moderately larger, but the European ice sheet extends more eastward and in eastern Siberia a relatively large glaciation develops. The low absorption efficiency of $\mathrm{RI}=0.0005$ produces a substantial increase in extent and elevation of North American ice and an unrealistically large zonally expanding ice sheet covering the entirety of northern Eurasia (Fig. 9).

The feedbacks between climate, ice sheets and dust cycle implicate different geographical distributions of forcing and response. This is seen from comparing the zonal means of dust DRF for LGM and present-day conditions (Fig. 6c and d) with zonal mean responses in SAT, precipitation and dust AOT obtained in the six DRF-driven simulation experiments (Fig. 10). The zonal mean responses in SAT (Fig. 10a, b) and precipitation (Fig. 10c, d) induced by dust DRF are shown relative to the control simulation without dust DRF. The zonal mean responses in dust AOT (Fig. 10e, f) obtained with a high dust lifetime in solution L1 and a low dust lifetime in solution L2 are shown, respectively, relative to the corresponding solutions L1 and L2 without DRF (Fig. 6a, b). The DRF-induced mean SAT changes are largest in high northern latitudes where zonal 
means of SAT are below the freezing point and the ice-albedo and snow-albedo feedbacks are effective (Fig. 10a, b). The zonal mean precipitation changes are relatively large in the northern tropical rain belt $0-10^{\circ} \mathrm{N}$ and also in the latitude band $50-60^{\circ} \mathrm{N}$ (Fig. 10c, d). The use of RI $=0.0060$ leads to substantial reduction of dust AOT in the northern latitudes at LGM and present day (Fig. 10e, f) and explains the minor responses in SAT (Fig. 10a, b) and precipitation (Fig. 10c, d). The use of RI $=0.0015$ leads to slightly lower dust AOT in northern subtropical latitudes at LGM and present day, which coincide with a cooler and dryer climate. However, at LGM the dust AOT increases at high northern latitudes, which is largely connected with dryer climate and reduced wet deposition. The use of $\mathrm{RI}=0.0005$ produces a strong increase in dust AOT at LGM in subtropical and mid-latitudes, which is associated with a strong northward growing cooling and a reduction in precipitation in low and mid-latitudes.

The zonal means in dust AOT, TOA radiative forcing and induced SAT change for LGM and present day agree qualitatively with results presented in Mahowald et al. (2006b). However, the simulation experiments conducted with the medium absorption efficiency suggest that the SAT response in northern latitudes can be about twice as strong as in the simulations shown in Mahowald et al. (2006b) for LGM and present-day conditions. The simulated SAT response shows a polar amplification as discussed in Lambert et al. (2013). The results suggest that the amplified cooling in the northern high latitudes is closely connected with the dust DRF. The dust DRF is concentrated in the Northern Hemisphere and is especially effective over Asia where the climate response is amplified through the positive ice-albedo feedback.

\section{Conclusions}

Aeolian dust potentially plays an important role in understanding the Pleistocene ice ages, which is suggested by correlations between climate and dust deposition records. The present study presents transient simulations of glacial cycles using the CLIMBER-2 model, which includes models for the atmosphere, the ocean, the vegetation, the ice sheets and the aeolian dust cycle. The focus is on how climate system properties could influence the distribution of aeolian dust, and how changes in the radiative energy budget of the Earth induced by dust aerosols could affect the glacial-interglacial climate evolution. The interplay between large-scale climate characteristics and micro-physical properties of dust aerosols is described in an efficient way for testing the possible impact of the direct shortwave radiative forcing by aeolian dust in long-term simulations.

The atmospheric distribution of dust and the absorptionscattering efficiency of dust aerosols are identified as key elements controlling the dust SW DRF. Constraints for presentday atmospheric dust lifetime, for past and present dust deposition fluxes and for the imaginary RI are available from
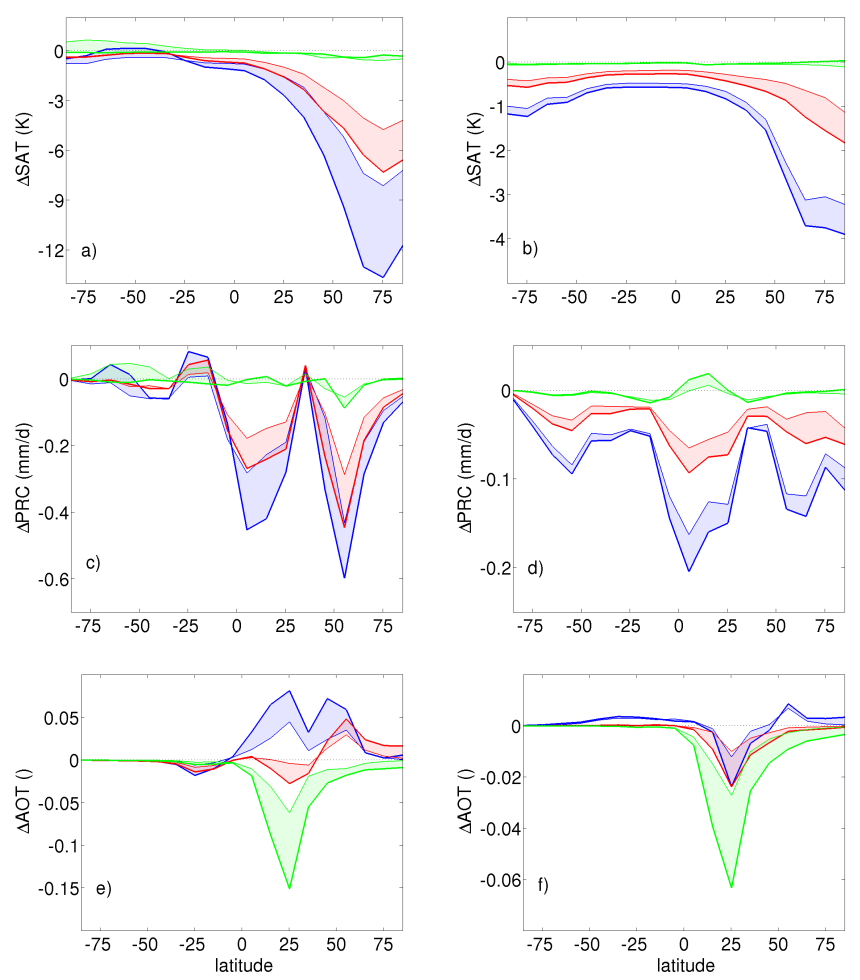

Figure 10. Zonal means of response to dust SW DRF from six simulations experiments for SAT in $\mathrm{K}(\mathbf{a}, \mathbf{b})$, precipitation in $\mathrm{mm} \mathrm{d}^{-1}$ (c, d) and dust AOT (e, f) for $21 \mathrm{kyr}(\mathbf{a}, \mathbf{c}, \mathbf{e})$ and $0 \mathrm{ka} \mathrm{(b,} \mathrm{d,} \mathrm{f).} \mathrm{Note}$ responses of SAT and precipitation are relative to control simulation and responses of dust AOT are relative to corresponding solutions L1 and L2 shown in Fig. 6a, b. Colour shading and line width as in Fig. 5.

analyses of various data and simulations with general circulation models. These constraints define a set of simulation experiments which account for high and low values in dust load and RI. The resulting mean shortwave DRF by aeolian dust spans a wide uncertainty range. For LGM climate at $21 \mathrm{ka}$, the dust DRF at TOA ranges from -0.92 to $+0.04 \mathrm{~W} \mathrm{~m}^{-2}$ and for present day climate from -0.59 to $-0.06 \mathrm{~W} \mathrm{~m}^{-2}$. Yet, these values are in the range obtained from time slice simulations with general circulation models (Claquin et al., 2003; Takemura et al., 2009).

The dust DRF simulated with the different parameter settings is applied for the first time in different simulations to study glacial cycles with the intermediate-complexity Earth system model CLIMBER-2. The main conclusions from these simulation experiments are as follows. First, the dust DRF is highly localized with annual mean values of several watts per square metre in the regions close to major dust sources and negligible values elsewhere. Therefore, global means of dust DRF should be used with caution for estimating its global-scale impact on temperature. Second, the dust DRF is a nonlinear function of insolation, dust load, surface albedo, cloudiness and absorption-scattering efficiency 
leading to variable strength in dust DRF and even to an uncertain sign in dust DRF. This is an explanation of the wide uncertainty range of dust DRF. Third, the dust DRF induces changes in temperature and precipitation fields. This climate response is found strongly sensitive to dust distribution and to absorption efficiency because the dust cycle is part of a feedback loop. In simulations with high dust load and low RI of 0.0005 , the dust DRF is negative and the induced global SAT cooling is $2.3 \mathrm{~K}$ at $\mathrm{LGM}$ and $1.1 \mathrm{~K}$ at present day compared to the control simulation without dust DRF. The cooling and associated drying of the climate leads to an amplified dust load and in turn to a stronger negative DRF followed by a significant increase in glacial ice sheets. Inversely, simulations with a high RI of 0.0060 produce a weak or positive dust DRF, and the mean SAT is about unchanged compared to the control simulation. That small dust DRF leads to a reduced dust load and a further weakening of dust DRF, implying a negligible climate response. When the dust DRF is calculated with a medium RI of 0.0015 , a moderate additional cooling is simulated and the simulated dust cycle characteristics are similar to those of the control simulation.

Our simulations indicate that inclusion of the interactive dust cycle into the Earth system model can be important for simulations of glacial cycles. Even though the global dust DRF is small compared to greenhouse gas forcing, it can alter the climate and the global ice volume through feedback mechanisms. Present results are based on the assumption that the absorption and scattering effects of aeolian dust can be described by effective optical parameters for dust mass extinction and refraction at visible wavelengths. This assumption relies on present-day data analyses. It is unclear whether the assumption holds also for different climate conditions. Another caveat of the present dust cycle model is that the transport and deposition schemes aggregate the natural range of dust particles into a typical bin. This limitation is due to a lack of adequate information on physical and chemical properties of dust particles emitted from different sources and different climates. Likewise effects from longwave radiative forcing and indirect effects from interactions between aerosols and clouds are currently not considered.
The present work describes a new step toward a fully coupled Earth system model. Further investigations are needed, in particular, for dust of glaciogenic production and its interaction with the ice sheet evolution. This will contribute to a consistent treatment of the dust deposition on snow and ice fields and also to ongoing research on the interactions between the dust cycle and the global carbon cycle.

Acknowledgements. The authors kindly thank both anonymous reviewers for their valuable comments that helped to improve the paper. The author E. B. thanks Mark Lawrence at the Institute for Advanced Sustainability Studies (IASS) in Potsdam, Germany for support in the study.

Edited by: M. Claussen 


\section{Appendix A: Complex refractive index}

The complex refractive index is an essential parameter in the radiative transport equation of light through the atmosphere. In the present study, the scattering and absorption of light by atmospheric particles is described by the two-stream deltaEddington approximation as a function of the cosine of the solar zenith angle, of the optical depth of aerosols and the imaginary part of the aerosol refractive index (RI). The real part of the refractive index of 1.5 is in reasonable agreement with data (Otto et al., 2009). RI is zero if the scattering particles are non-absorbing. Values of RI are inferred by use of theoretical spectral models, spectral measurements and particle property distributions. Dubovik et al. (2002) and references therein give an overview of the methodology and about RI values for dust aerosols. Recent measurements from the Saharan Mineral Dust Experiment (SAMUM) over Morocco give size-resolved values for RI between 0.0008 and 0.0060 at $0.55 \mu \mathrm{m}$ wavelength (Otto et al., 2009). Aircraft measurements during the Saharan Dust Experiment (SHADE) suggest $\mathrm{RI}=0.0015$ to be appropriate at $0.55 \mu \mathrm{m}$ wavelength (Haywood et al., 2003). During the Dust and Biomass Burning Experiment (DABEX) over northern Africa a minimum value of $R I=0.0004$ is obtained from aircraft measurements for dust aerosols at $0.55 \mu \mathrm{m}$ wavelength (Osborne et al., 2008). The model studies by Takemura et al. (2005) and Takemura et al. (2009) used RI $=0.0020$ for soil dust. The present study considers RI between 0.0005 and 0.0060 . 


\section{References}

Anderson, R., Fleisher, M., and Lao, Y.: Glacial-interglacial variability in the delivery of dust to the central equatorial Pacific Ocean, Earth Planet. Sci. Lett., 242, 406-414, 2006.

Archer, D., Winguth, A., Lea, D., and Mahowald, N.: What caused the glacial/interglacial atmospheric $p \mathrm{CO}_{2}$ cycles?, Rev. Geophys., 38, 159-189, 2000.

Augustin, L., Barbante, C., Barnes, P. R. F., Barnola, J. M., Bigler, M., Castellano, E., Cattani, O., Chappellaz, J., Dahl-Jensen, D., Delmonte, B., Dreyfus, G., Durand, G., Falourd, S., Fischer, H., Flückiger, J., Hansson, M. E., Huybrechts, P., Jugie, G., Johnsen, S. J., Jouzel, J., Kaufmann, P., Kipfstuhl, J., Lambert, F., Lipenkov, V. Y., Littot, G. C., Longinelli, A., Lorrain, R., Maggi, V., Masson-Delmotte, V., Miller, H., Mulvaney, R., Oerlemans, J., Oerter, H., Orombelli, G., Parrenin, F., Peel, D. A., Petit, J.-R., Raynaud, D., Ritz, C., Ruth, U., Schwander, J., Siegenthaler, U., Souchez, R., Stauffer, B., Steffensen, J. P., Stenni, B., Stocker, T. F., Tabacco, I. E., Udisti, R., Van De Wal, R. S. W., Van Den Broeke, M., Weiss, J., Wilhelms, F., Winther, J.-G., Wolff, E. W., and Zucchelli, M.: Eight glacial cycles from an Antarctic ice core., Nature, 429, 623-628, 2004.

Balkanski, Y., Schulz, M., Claquin, T., and Guibert, S.: Reevaluation of Mineral aerosol radiative forcings suggests a better agreement with satellite and AERONET data, Atmos. Chem. Phys., 7, 81-95, doi:10.5194/acp-7-81-2007, 2007.

Bauer, E. and Ganopolski, A.: Aeolian dust modeling over the past four glacial cycles with CLIMBER-2, Glob. Planet. Change, 74, 49-60, 2010.

Bauer, E., Ganopolski, A., and Montoya, M.: Simulation of the cold climate event 8200 years ago by meltwater outburst from Lake Agassiz, Paleoceanography, 19, PA3014, doi:10.1029/2004PA001030, 2004.

Bauer, E., Petoukhov, V., Ganopolski, A., and Eliseev, A. V.: Climatic response to anthropogenic sulphate aerosols versus wellmixed greenhouse gases from 1850 to 2000 AD in CLIMBER-2, Tellus, 60B, 82-97, 2008.

Berger, A., Loutre, M.-F., and Tricot, C.: Insolation and Earth's orbital periods, J. Geophys. Res., 98, 10341-10362, 1993.

Berger, A. L.: Long-term variations of daily insolation and Quaternary climatic changes, J. Atmos. Sci., 35, 2362-2367, 1978.

Bonelli, S., Charbit, S., Kageyama, M., Woillez, M.-N., Ramstein, G., Dumas, C., and Quiquet, A.: Investigating the evolution of major Northern Hemisphere ice sheets during the last glacialinterglacial cycle, Clim. Past, 5, 329-345, doi:10.5194/cp-5-3292009, 2009.

Bopp, L., Kohfeld, K. E., Le Quéré, C., and Aumont, O.: Dust impact on marine biota and atmospheric $\mathrm{CO}_{2}$ during glacial periods, Paleoceanography, 18, 1046, 2003.

Brovkin, V., Bendtsen, J. r., Claussen, M., Ganopolski, A., Kubatzki, C., Petoukhov, V., and Andreev, A.: Carbon cycle, vegetation, and climate dynamics in the Holocene: Experiments with the CLIMBER-2 model, Global Biogeochem. Cy., 16, 1139, 2002.

Brovkin, V., Ganopolski, A., Archer, D., and Rahmstorf, S.: Lowering of glacial atmospheric $\mathrm{CO}_{2}$ in response to changes in oceanic circulation and marine biogeochemistry, Paleoceanography, 22, PA4202, doi:10.1029/2006PA001380, 2007.

Brovkin, V., Ganopolski, A., Archer, D., and Munhoven, G.: Glacial $\mathrm{CO}_{2}$ cycle as a succession of key physical and biogeochemical processes, Clim. Past, 8, 251-264, doi:10.5194/cp-8-251-2012, 2012.

Cakmur, R. V., Miller, R. L., Perlwitz, J., Geogdzhayev, I. V., Ginoux, P., Koch, D., Kohfeld, K. E., Tegen, I., and Zender, C. S.: Constraining the magnitude of the global dust cycle by minimizing the difference between a model and observations, J. Geophys. Res., 111, D06207, 2006.

Calov, R., Ganopolski, A., Claussen, M., Petoukhov, V., and Greve, R.: Transient simulation of the last glacial inception - Part I: glacial inception as a bifurcation in the climate system, Clim. Dynam., 24, 545-561, 2005.

Chin, M., Ginoux, P., and Kinne, S.: Tropospheric aerosol optical thickness from the GOCART model and comparisons with satellite and Sun photometer measurements, J. Atmos. Sci., 59, 461483, 2002.

Christopher, S. a. and Jones, T.: Satellite-based assessment of cloudfree net radiative effect of dust aerosols over the Atlantic Ocean, Geophys. Res. Lett., 34, L02810, doi:10.1029/2006GL027783, 2007.

Claquin, T., Schulz, M., Balkanski, Y., and Boucher, O.: Uncertainties in assessing radiative forcing by mineral dust, Tellus, 50, 491-505, 1998.

Claquin, T., Roelandt, C., Kohfeld, K. E., Harrison, S. P., Tegen, I., Prentice, I. C., Balkanski, Y., Bergametti, G., Hansson, M., Mahowald, N., Rohde, H., and Schulz, M.: Radiative forcing of climate by ice-age atmospheric dust, Clim. Dynam., 20, 193202, 2003.

Claussen, M., Mysak, L., Weaver, A., Crucifix, M., Fichefet, T., Loutre, M.-F., Weber, S., Alcamo, J., Alexeev, V., Berger, A., Calov, R., Ganopolski, A., Goosse, H., Lohmann, G., Lunkeit, F., Mokhov, I., Petoukhov, V., Stone, P., and Wang, Z.: Earth system models of intermediate complexity: closing the gap in the spectrum of climate system models, Clim. Dynam., 18, 579-586, 2002.

Dentener, F., Kinne, S., Bond, T., Boucher, O., Cofala, J., Generoso, S., Ginoux, P., Gong, S., Hoelzemann, J. J., Ito, A., Marelli, L., Penner, J. E., Putaud, J.-P., Textor, C., Schulz, M., van der Werf, G. R., and Wilson, J.: Emissions of primary aerosol and precursor gases in the years 2000 and 1750 prescribed data-sets for AeroCom, Atmos. Chem. Phys., 6, 4321-4344, doi:10.5194/acp-64321-2006, 2006.

Dubovik, O., Holben, B., Eck, T. F., Smirnov, A., Kaufman, Y. J., King, M. D., Tanre, D., and Slutsker, I.: Variability of absorption and optical properties of key aerosol types observed in worldwide locations, J. Atmos. Sci., 59, 590-608, 2002.

Ganopolski, A. and Calov, R.: The role of orbital forcing, carbon dioxide and regolith in $100 \mathrm{kyr}$ glacial cycles, Clim. Past, 7, 1415-1425, doi:10.5194/cp-7-1415-2011, 2011.

Ganopolski, A. and Roche, D. M.: On the nature of lead-lag relationships during glacial-interglacial climate transitions, Quat. Sci. Rev., 28, 3361-3378, 2009.

Ganopolski, A., Kubatzki, C., Claussen, M., Brovkin, V., and Petoukhov, V.: The influence of vegetation-atmosphere-ocean interaction on climate during the mid-Holocene, Science, 280 , 1916-1919, 1998.

Ganopolski, A., Petoukhov, V., Rahmstorf, S., Brovkin, V., Claussen, M., Eliseev, A., and Kubatzki, C.: CLIMBER-2: a climate system model of intermediate complexity. Part II: model sensitivity, Clim. Dynam., 17, 735-751, 2001. 
Ganopolski, A., Calov, R., and Claussen, M.: Simulation of the last glacial cycle with a coupled climate ice-sheet model of intermediate complexity, Clim. Past, 6, 229-244, doi:10.5194/cp-6-2292010, 2010.

Ginoux, P., Horowitz, L. W., Ramaswamy, V., Geogdzhayev, I. V., Holben, B. N., Stenchikov, G., and Tie, X.: Evaluation of aerosol distribution and optical depth in the Geophysical Fluid Dynamics Laboratory coupled model CM2.1 for present climate, J. Geophys. Res., 111, D22210, doi:10.1029/2005JD006707, 2006.

Greve, R.: A continuum-mechanical formulation for shallow polythermal ice sheets, Philos. T. Roy. Soc. Lond. A, 335, 921-974, 1997.

Grini, A., Myhre, G., Zender, C. S., and Isaksen, I. S. A.: Model simulations of dust sources and transport in the global atmosphere: Effects of soil erodibility and wind speed variability, J. Geophys. Res., 110, D02205, doi:10.1029/2004JD005037, 2005.

Haxeltine, A. and Prentice, I. C.: BIOME 3: an equilibrium terrestrial biosphere model based on ecophysiological constraints, ressource availability and competition among plant functionnal types, Global Biogeochem. Cy., 10, 693-709, 1996.

Haywood, J., Francis, P., Osborne, S., Glew, M., Loeb, N., Highwood, E., Tanre, D., Myhre, G., Formenti, P., and Hirst, E.: Radiative properties and direct radiative effect of Saharan dust measured by the C-130 aircraft during SHADE: 1. Solar spectrum, J. Geophys. Res., 108, 8577, doi:10.1029/2002JD002687, 2003.

Kinne, S., Schulz, M., Textor, C., Guibert, S., Balkanski, Y., Bauer, S. E., Berntsen, T., Berglen, T. F., Boucher, O., Chin, M., Collins, W., Dentener, F., Diehl, T., Easter, R., Feichter, J., Fillmore, D., Ghan, S., Ginoux, P., Gong, S., Grini, A., Hendricks, J., Herzog, M., Horowitz, L., Isaksen, I., Iversen, T., Kirkevåg, A., Kloster, S., Koch, D., Kristjansson, J. E., Krol, M., Lauer, A., Lamarque, J. F., Lesins, G., Liu, X., Lohmann, U., Montanaro, V., Myhre, G., Penner, J., Pitari, G., Reddy, S., Seland, O., Stier, P., Takemura, T., and Tie, X.: An AeroCom initial assessment - optical properties in aerosol component modules of global models, Atmos. Chem. Phys., 6, 1815-1834, doi:10.5194/acp-6-1815-2006, 2006.

Kohfeld, K. E. and Harrison, S. P.: DIRTMAP: the geological record of dust, Earth-Sci. Rev., 54, 81-114, 2001.

Krinner, G., Boucher, O., and Balkanski, Y.: Ice-free glacial northern Asia due to dust deposition on snow, Clim. Dynam., 27, 613625, 2006

Lambert, F., Delmonte, B., Petit, J. R., Bigler, M., Kaufmann, P. R., Hutterli, M. A., Stocker, T. F., Ruth, U., Steffensen, J. P., and Maggi, V.: Dust-climate couplings over the past 800,000 years from the EPICA Dome C ice core., Nature, 452, 616-619, 2008.

Lambert, F., Kug, J.-S., Park, R. J., Mahowald, N., Winckler, G., Abe-Ouchi, A., O'ishi, R., Takemura, T., and Lee, J.-H.: The role of mineral-dust aerosols in polar temperature amplification, Nat. Clim. Change, 3, 487-491, doi:10.1038/nclimate1785, 2013.

Liao, H. and Seinfeld, J. H.: Radiative forcing by mineral dust aerosols: sensitivity to key variables, J. Geophys. Res., 103, 31637-31645, 1998.

Liao, H., Seinfeld, J. H., Adams, P. J., and Mickley, L. J.: Global radiative forcing of coupled tropospheric ozone and aerosols in a unified general circulation model, J. Geophys. Res., 109, D16207, doi:10.1029/2003JD004456, 2004.
Lunt, D. J. and Valdes, P. J.: The modern dust cycle: Comparison of model results with observations and study of sensitivities, J. Geophys. Res., 107, 4669, doi:10.1029/2002JD002316, 2002.

Luo, C., Mahowald, N. M., and del Corral, J.: Sensitivity study of meteorological parameters on mineral aerosol mobilization, transport, and distribution, J. Geophys. Res., 108, 4447 doi:10.1029/2003JD003483, 2003.

Maher, B. A., Prospero, J. M., Mackie, D., Gaiero, D., Hesse, P. P., and Balkanski, Y.: Global connections between aeolian dust, climate and ocean biogeochemistry at the present day and at the last glacial maximum, Earth-Sci. Rev., 99, 61-97, 2010.

Mahowald, N., Kohfeld, K., Hansson, M., Balkanski, Y., Harrison, S. P., Prentice, I. C., Schulz, M., and Rodhe, H.: Dust sources and deposition during the last glacial maximum and current climate: A comparison of model results with paleodata from ice cores and marine sediments, J. Geophys. Res., 104, 15895-15916, 1999.

Mahowald, N. M., Muhs, D. R., Levis, S., Rasch, P. J., Yoshioka, M., Zender, C. S., and Luo, C.: Change in atmospheric mineral aerosols in response to climate: Last glacial period, preindustrial, modern, and doubled carbon dioxide climates, J. Geophys. Res., 111, D10202, doi:10.1029/2005JD006653, 2006a.

Mahowald, N. M., Yoshioka, M., Collins, W. D., Conley, A. J., Fillmore, D. W., and Coleman, D. B.: Climate response and radiative forcing from mineral aerosols during the last glacial maximum, pre-industrial, current and doubled-carbon dioxide climates, Geophys. Res. Lett., 33, L20705, doi:10.1029/2006GL026126, 2006b.

Martin, J. H.: Glacial-interglacial $\mathrm{CO}_{2}$ change: The iron hypothesis, Paleoceanography, 5, 1-13, 1990.

McGee, D., Broecker, W. S., and Winckler, G.: Gustiness: The driver of glacial dustiness?, Quat. Sci. Rev., 29, 2340-2350, 2010.

Miller, R. L., Cakmur, R. V., Perlwitz, J., Geogdzhayev, I. V., Ginoux, P., Koch, D., Kohfeld, K. E., Prigent, C., Ruedy, R., Schmidt, G. A., and Tegen, I.: Mineral dust aerosols in the NASA Goddard Institute for Space Sciences ModelE atmospheric general circulation model, J. Geophys. Res., 111, D06208, doi:10.1029/2005JD005796, 2006.

Myhre, G. and Stordal, F.: Global sensitivity experiments of the radiative forcing due to mineral aerosols, J. Geophys. Res., 106 , 18193-18204, 2001.

Myhre, G., Grini, A., Haywood, J. M., Stordal, F., Chatenet, B., Tanre, D., Sundet, K., and Isaksen, I. S. A.: Modeling the radiative impact of mineral dust during the Saharan Dust Experiment (SHADE) campaign, J. Geophys. Res., 108, 8579, doi:10.1029/2002JD002566, 2003.

Osborne, S. R., Johnson, B. T., Haywood, J. M., Baran, A. J., Harrison, M. A. J., and McConnell, C. L.: Physical and optical properties of mineral dust aerosol during the Dust and Biomass-burning Experiment, J. Geophys. Res., 113, D00C03, doi:10.1029/2007JD009551, 2008.

Otto, S., Bierwirth, E., Weinzierl, B., Kandler, K., Esselborn, M. Tesche, M., Schladitz, A., Wendisch, M., and Trautmann, T.: Solar radiative effects of a Saharan dust plume observed during SAMUM assuming spheroidal model particles, Tellus B, 61, 270296, 2009.

Overpeck, J., Rind, D., Lacis, A., and Healy, R.: Possible role of dust-induced regional warming in abrupt climate change during the last glacial period, Nature, 384, 447-449, 1996. 
Patadia, F., Gupta, P., and Christopher, S. A.: First observational estimates of global clear sky shortwave aerosol direct radiative effect over land, Geophys. Res. Lett., 35, L04810, doi:10.1029/2007GL032314, 2008.

Patadia, F., Yang, E.-S., and Christopher, S. A.: Does dust change the clear sky top of atmosphere shortwave flux over high surface reflectance regions?, Geophys. Res. Lett., 36, L15825, doi:10.1029/2009GL039092, 2009.

Petit, J. R., Jouzel, J., Raynaud, D., Barkov, N. I., Barnola, J. M., Basile, I., Bender, M., Chappellaz, J., Davis, M., Delaygue, G., Delmotte, M., Kotlyakov, V. M., Legrand, M., Lipenkov, V. Y., Lorius, C., Pepin, L., Ritz, C., Saltzman, E., and Stievenard, M.: Climate and atmospheric history of the past 420,000 years from the Vostok ice core, Antarctica, Nature, 399, 429-436, 1999.

Petoukhov, V., Ganopolski, A., Brovkin, V., Claussen, M., Eliseev, A., Kubatzki, C., and Rahmstorf, S.: CLIMBER-2: a climate system model of intermediate complexity. Part I: model description and performance for present climate, Clim. Dynam., 16, 1-17, 2000.

Reddy, M. S., Boucher, O., Balkanski, Y., and Schulz, M.: Aerosol optical depths and direct radiative perturbations by species and source type, Geophys. Res. Lett., 32, L12803, doi:10.1029/2009GL039092, 2005.

Schneider von Deimling, T., Held, H., Ganopolski, A., and Rahmstorf, S.: Climate sensitivity estimated from ensemble simulations of glacial climate, Clim. Dynam., 27, 149-163, 2006.

Shettle, E. and Weinman, J.: The transfer of solar irradiance through inhomogeneous turbid atmospheres evaluated by Eddington's approximation, J. Atmos. Sci., 27, 1048-1055, 1970.

Sow, M., Alfaro, S. C., Rajot, J. L., and Marticorena, B.: Size resolved dust emission fluxes measured in Niger during 3 dust storms of the AMMA experiment, Atmos. Chem. Phys., 9, 38813891, doi:10.5194/acp-9-3881-2009, 2009.

Takemura, T., Nakajima, T., Dubovik, O., Holben, B. N., and Kinne, S.: Single-Scattering Albedo and Radiative Forcing of Various Aerosol Species with a Global Three-Dimensional Model, J. Clim., 15, 333-352, 2002.

Takemura, T., Nozawa, T., Emori, S., Nakajima, T. Y., and Nakajima, T.: Simulation of climate response to aerosol direct and indirect effects with aerosol transport-radiation model, J. Geophys. Res., 110, D02202, doi:10.1029/2004JD005029, 2005.

Takemura, T., Egashira, M., Matsuzawa, K., Ichijo, H., O’ishi, R., and Abe-Ouchi, A.: A simulation of the global distribution and radiative forcing of soil dust aerosols at the Last Glacial Maximum, Atmos. Chem. Phys., 9, 3061-3073, doi:10.5194/acp-93061-2009, 2009.

Tanaka, T. Y. and Chiba, M.: A numerical study of the contributions of dust source regions to the global dust budget, Glob. Planet. Change, 52, 88-104, 2006.

Tegen, I. and Lacis, A. A.: Modeling of particle size distribution and its influence on the radiative properties of mineral dust aerosol, J. Geophys. Res., 101, 19237-19244, 1996.

Tegen, I., Lacis, A. A., and Fung, I.: The influence on climate forcing of mineral aerosols from disturbed soils, Nature, 380, 419422, 1996.

Tegen, I., Harrison, S. P., Kohfeld, K., and Prentice, I. C.: Impact of vegetation and preferential source areas on global dust aerosol: Results from a model study, J. Geophys. Res., 107, 4576, doi:10.1029/2001JD000963, 2002.
Textor, C., Schulz, M., Guibert, S., Kinne, S., Balkanski, Y., Bauer, S., Berntsen, T., Berglen, T., Boucher, O., Chin, M., Dentener, F., Diehl, T., Easter, R., Feichter, H., Fillmore, D., Ghan, S., Ginoux, P., Gong, S., Grini, A., Hendricks, J., Horowitz, L., Huang, P., Isaksen, I., Iversen, I., Kloster, S., Koch, D., Kirkevåg, A., Kristjansson, J. E., Krol, M., Lauer, A., Lamarque, J. F., Liu, X., Montanaro, V., Myhre, G., Penner, J., Pitari, G., Reddy, S., Seland, $\emptyset .$, Stier, P., Takemura, T., and Tie, X.: Analysis and quantification of the diversities of aerosol life cycles within AeroCom, Atmos. Chem. Phys., 6, 1777-1813, doi:10.5194/acp-6-1777-2006, 2006.

Textor, C., Schulz, M., Guibert, S., Kinne, S., Balkanski, Y., Bauer, S., Berntsen, T., Berglen, T., Boucher, O., Chin, M., Dentener, F., Diehl, T., Feichter, J., Fillmore, D., Ginoux, P., Gong, S., Grini, A., Hendricks, J., Horowitz, L., Huang, P., Isaksen, I. S. A., Iversen, T., Kloster, S., Koch, D., Kirkevåg, A., Kristjansson, J. E., Krol, M., Lauer, A., Lamarque, J. F., Liu, X., Montanaro, V., Myhre, G., Penner, J. E., Pitari, G., Reddy, M. S., Seland, Ø., Stier, P., Takemura, T., and Tie, X.: The effect of harmonized emissions on aerosol properties in global models an AeroCom experiment, Atmos. Chem. Phys., 7, 4489-4501, doi:10.5194/acp-7-4489-2007, 2007.

Waelbroeck, C., Labeyrie, L., Michel, E., Duplessy, J., McManus, J., Lambeck, K., Balbon, E., and Labracherie, M.: Sea-level and deep water temperature changes derived from benthic foraminifera isotopic records, Quat. Sci. Rev., 21, 295-305, 2002.

Waelbroeck, C., Paul, A., Kucera, M., Rosell-Melé, A., Weinelt, M., Schneider, R., Mix, A. C., Abelmann, A., Armand, L., Bard, E., Barker, S., Barrows, T. T., Benway, H., Cacho, I., Chen, M.T., Cortijo, E., Crosta, X., de Vernal, A., Dokken, T., Duprat, J., Elderfield, H., Eynaud, F., Gersonde, R., Hayes, A., Henry, M., Hillaire-Marcel, C., Huang, C.-C., Jansen, E., Juggins, S., Kallel, N., Kiefer, T., Kienast, M., Labeyrie, L., Leclaire, H., Londeix, L., Mangin, S., Matthiessen, J., Marret, F., Meland, M., Morey, A. E., Mulitza, S., Pflaumann, U., Pisias, N. G., Radi, T., Rochon, A., Rohling, E. J., Sbaffi, L., Schäfer-Neth, C., Solignac, S., Spero, H., Tachikawa, K., and Turon, J.-L.: Constraints on the magnitude and patterns of ocean cooling at the Last Glacial Maximum, Nat. Geosci., 2, 127-132, 2009.

Warren, S. G. and Wiscombe, W. J.: A model for the spectral albedo of snow. II: snow containing atmospheric aerosols, Journal of the Atmospheric Sciences, 37, 2734-2745, 1980.

Watson, A. J., Bakker, D. C. E., Ridgwell, A. J., Boyd, P. W., and Law, C. S.: Effect of iron supply on Southern Ocean CO2 uptake and implications for glacial atmospheric $\mathrm{CO}_{2}$, Nature, 407, 730733, 2000.

Werner, M., Tegen, I., Harrision, S. P., Kohfeld, K. E., Prentice, I. C., Balkanski, Y., Rohde, H., and Roelandt, C.: Seasonal and interannual variability of the mineral dust cycle under present and glacial climate conditions, J. Geophys. Res., 107, 4744, doi:10.1029/2002JD002365, 2002.

Winckler, G., Anderson, R. F., Fleisher, M. Q., McGee, D., and Mahowald, N.: Covariant glacial-interglacial dust fluxes in the equatorial Pacific and Antarctica, Science, 320, 93-96, 2008.

Yang, E.-S., Gupta, P., and Christopher, S. A.: Net radiative effect of dust aerosols from satellite measurements over Sahara, Geophys. Res. Lett., 36, L18812, doi:10.1029/2009GL039801, 2009. 